\title{
The Impact of Environmental Turbulence and Dynamic Capabilities Toward Business Unit Performance (Case Study at Communication Organization Industries)
}

\author{
S.K. Ermaya *, L.A. Wibowo \\ Universitas Pendidikan Indonesia \\ Bandung, Indonesia \\ *liliadiwibowo@upi.edu
}

\begin{abstract}
Superior business performance is determined by the ability of business units to create competitive advantage. However, the rapid development of technology and market make uncertain condition on business environment. This condition is known as environmental turbulence. This research aims to investigate the impact of environmental turbulence and dynamic capabilities on business unit performance in communication industry in Indonesia. The methods used were descriptive survey method and explanatory survey method. The population was telecommunication operator business unit in Indonesia. The data was taken from The Ministry of Communication and Information. The result showed that the direct impact of environmental turbulence on business unit performance was 0.104. The direct impact of dynamic capabilities on business unit performance was 0.220 . Meanwhile, the score of (impact from unknown variables) was 0.214 . This result implied that: 1) environmental turbulence had more significant influence on business unit performance compared to dynamic capabilities and 2) dynamic capability was the key factor in improving business unit performance.
\end{abstract}

Keywords-Environmental Turbulence; Dynamic Capabilities; Business Unit Performance

\section{INTRODUCTION}

In this innovation era, telecommunication industry becomes more dynamic. This condition demands the player of the industry to be more competitive. Telecommunication company managements do various actions to get the large market share and to become the market leader. They also want to have a competitive advantages. By having the superior goods or services, the companies will dominate the market both domestic and global market. This competition of course will be impacted to the economic growth. The research done by [1] in over 120 countries from 1980 to 2006 showed the positive impact of enhancing of telecommunication services on the growth of economics.

\section{LITERATURE REVIEW}

Regarding the performance of telecommunication in Indonesia, it still considered as low. In the South Asia level, its telephone density (teledensity) still stays under neighboring countries, such Singapore, Malaysia, Thailand, Philippine etc.
The data ICT in southeast asia 2016 per 100 citizens can be seen below:

$\begin{array}{lll}\text { 1. } & \text { Singapore: } & 35.04 \\ \text { 2. } & \text { Malaysia: } & 14.50 \\ \text { 3. } & \text { Thailand: } & 6.97 \\ \text { 4. } & \text { Vietnam: } & 5.94 \\ \text { 5. } & \text { Brunei: 17.11 } & \\ \text { 6. } & \text { Philippine: } & 3.71 \\ \text { 7. } & \text { Laos: 17.72 } & \\ \text { 8. } & \text { Cambodia: } & 1.43 \\ \text { 9. } & \text { Myanmar: } & 0.94 \\ \text { 10. } & \text { Indonesia: } & 4.01\end{array}$

The low performance of telecommunication industry in Indonesia is caused by the uncertainty condition of business environment. Turbulent environment occurs due to several factors, such as technology, regulation, competition, and market. The causes of environmental turbulence in telecommunication industry. To maintain the company performance in the middle of uncertainty condition, [2] suggest the company to adapt the organizational structure with the environment condition in which the organization carries out its activity. Thus, organizational performance will be optimal.

The causes of telecommunication environmental turbulence in Indonesia, can be seen below:

1. Enhancing digital convergence trend by consolidating the data processing technology impact on technology turbulence.

2. Privatization telecommunication sector Privatization as a consequence of WTO ratification (UU No. 7 / 94) which encourages opening market impact on regulation turbulence.

3. The change of telecommunication authority paradigm from monopolistic approach to market-based approach (UU No. 36 / 99) impact on regulation turbulence. 
environments. Previous studies divide environment into various dimensions. These dimension are then categorized into three main categories: munificence, complexity, and dynamism [6].

Capabilities refer to a company's skills to organize its resources and put them in productive use. This skill represents in company's rules, routines, and procedures. For example, it can be seen through decision-making process and internal management process [7]. [8] describe capability as the capacity of a firm to perform some internal activities competently. A dynamic capability is an ongoing capacity of a company to modify its existing resources and capabilities or create new ones [8].

[7] proposes that a business unit is a self-contained division (with its own function, for example, finance, purchasing, production, and marketing departments) that provides a product or service for a particular market. Performance is the accomplishment of a given task measured against preset known standards of accuracy, completeness, cost, and speed. (www.businessdictionary.com). [9] state that performance is the result of activities, including the outcome of strategic management process. The practice of strategic management is justified in terms of its ability to improve an organization's performance, which is typically measured in term of profits and return in investment. Meanwhile, business unit performance is a concept used to appraise the activities in a business unit.

\section{RESEARCH METHODOLOGY}

This research was descriptive and verificative. Descriptive research aimed to obtain an overview of environmental turbulence, dynamic capabilities, and business unit performance. Meanwhile, verification research aimed to test the relationship between these three variables.

Related to the method, this research used descriptive survey method and explanatory survey method. The first method was used to describe systematically and accurately the facts and characteristics of certain fields, while the second one was conducted to perform hypothesis testing procedures to answer the research problem. This research also used causality as the types of investigation. It was selected as it was able to investigate the relationship between variables based on the construction research model. In addition, cross-sectional or one shoot observation was also used. In this types of observation, the data was obtained in one particular time.

The population of this research was telecommunication operator business unit in Indonesia. The data was taken from The Ministry of Communication and Information. The population was taken by using the following formula:

\section{$\mathbf{n}=\mathbf{N} /\left(\mathbf{1}+\mathrm{Ne}^{2}\right)$}

Notes:

$\mathrm{n}=$ numbers of sample

$\mathrm{N}=$ numbers of population

$\mathrm{e}=$ critical points found in [5] work on the "causal texture" of organizational 
Table 2 shows that the correlation score between

There were two types of data in this research: primer and secondary data. These two data were collected by using several techniques, such as interview, observation, questionnaire, and documentation. In analyzing the data, construct validity and Alpha Cronbach Reliability test were used.

\section{RESULTS}

\section{A. Descriptive Statistics}

The result of managers' opinion toward three variable is provided below:

Table 1 descriptive analysis

\begin{tabular}{cccc}
\hline Variable & $\mathbf{N}$ & Mean & Interpretation \\
\hline $\begin{array}{c}\mathrm{X}_{1} \text { Environmental } \\
\text { Turbulence }\end{array}$ & 19 & 3,78 & Good \\
\hline $\mathrm{X}_{2}$ Dynamic Capabilities & 18 & 3,92 & Good \\
\hline $\begin{array}{c}\text { Y Business Unit } \\
\text { Performance }\end{array}$ & 13 & 3,33 & Fair \\
\hline
\end{tabular}

Source: data procced 2018

\section{B. Correlation Analysis}

Correlation was included into multivariate analysis as it investigated the relationship among two or more variables simultaneously. The purpose of correlation analysis was to test the significant relationship among variables. The result of correlation among the variable of this research can be seen in the following table:

Table 2. Correlation among variables.

\begin{tabular}{|c|c|c|c|c|}
\hline & & $\begin{array}{l}\text { Environmen } \\
\text { t Turb }\end{array}$ & $\begin{array}{c}\text { Dynami } \\
\text { c Cap }\end{array}$ & $\begin{array}{c}\text { BU } \\
\text { Performanc } \\
\mathrm{e} \\
\end{array}$ \\
\hline \multirow[t]{3}{*}{$\begin{array}{c}\text { Environm } \\
\text { ental } \\
\text { Turb } \\
\end{array}$} & $\begin{array}{c}\text { Pearson } \\
\text { Correlatio } \\
\mathrm{n} \\
\end{array}$ & 1 & $.617 * *$ & $.642 * *$ \\
\hline & $\begin{array}{l}\text { Sig (2- } \\
\text { tailed) }\end{array}$ & & .000 & .000 \\
\hline & $\mathrm{N}$ & 30 & 30 & 30 \\
\hline \multirow[t]{3}{*}{$\begin{array}{c}\text { Dynamic } \\
\text { Cap }\end{array}$} & $\begin{array}{c}\text { Pearson } \\
\text { Correlatio } \\
n\end{array}$ & $.617 * *$ & 1 & $.593 * *$ \\
\hline & $\begin{array}{l}\text { Sig (2- } \\
\text { tailed) }\end{array}$ & .000 & & .000 \\
\hline & $\mathrm{N}$ & 30 & 30 & 30 \\
\hline \multirow[t]{3}{*}{$\begin{array}{c}\text { BU } \\
\text { Performa } \\
\text { nce } \\
\end{array}$} & $\begin{array}{c}\text { Pearson } \\
\text { Correlatio } \\
n \\
\end{array}$ & $.642 * *$ & .539 & 1 \\
\hline & $\begin{array}{l}\text { Sig (2- } \\
\text { tailed) }\end{array}$ & .000 & .000 & \\
\hline & $\mathrm{N}$ & 30 & 30 & 30 \\
\hline
\end{tabular}

Source: data procced 2018 environmental turbulence and dynamic capabilities was 0.617. It also reveals that the correlation score between environmental turbulence and business unit performance was 0.642. Meanwhile, the correlation score between dynamic capabilities and business unit performances was 0.593. Based on the r-value, it can be concluded that all variables had strong enough correlation with positive value. Moreover, as the significance score $(0.000)$ was less than 0.0 .5 , this indicated that the correlation was significant. In short, environmental turbulence increases dynamic capabilities (0.617) and business unit performance (0.642), while dynamic capability increases business unit performance (0.593).

\section{Path Analysis}

When listing facts use either the style tag List signs or the style tag List numbers.

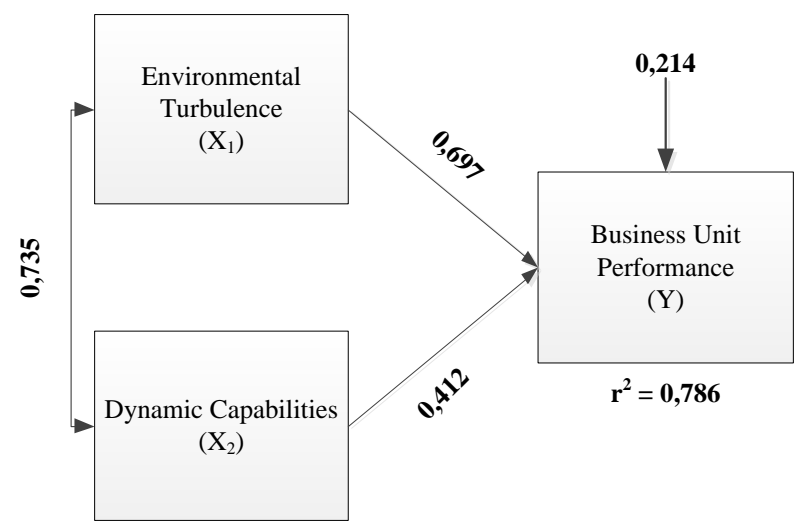

Figure 1. Result of Path Analysis

The result of path analysis is described in the following:

$$
\mathrm{Y}=0,697 \mathrm{X}_{1}+0,412 \mathrm{X}_{2}+\varepsilon
$$

Table 3. Direct and Indirect Impact (in \%)

\begin{tabular}{ccccc}
\hline Variable & $\begin{array}{c}\text { Direct Impact } \\
\text { to } \mathbf{Y}\end{array}$ & \multicolumn{2}{c}{ Indirect Impact } & \multirow{2}{*}{ ～Impact } \\
\cline { 3 - 4 } $\mathrm{X}_{1}$ & 0,104 & - & 0,231 & 0,335 \\
\hline $\mathrm{X}_{2}$ & 0,220 & 0,231 & - & 0,451 \\
\hline$\varepsilon$ & 0,214 & & & 0,786 \\
\hline
\end{tabular}

Source: data procced 2018

\section{CONCLUSION}

The telecommunication industry in Indonesia is experiencing a high environmental turbulence. This is mainly caused by turbulence in market and technological environment. The dynamic capabilities of the business unit are 
still unable to respond to environmental turbulence. This is mainly due to the lack of optimal coordination capability and inadequate integration capability. The performance of business units achieved by telecommunication organizations in Indonesia is not optimal yet. Some of them cannot gain the market share, investment returns and profit growth target. They also cannot produce innovative product that can attract new customers.

\section{REFERENCES}

[1] 2009. Economic Impacts of Broadband. In Information and Communications for Development 2009: Extending Reach and Increasing Impact, World Bank, WDC: 35 - 50

[2] Ansoff, H. I., McDonnell, E. 1990. Implanting Strategic Management. New York: Prentice Hall.
[3] Teece, David J. 2007. Explicating Dynamic Capabilities: The Nature and Microfoundations of (Sustainable) Enterprise Performance. Strategic Management Journal, 28 (13): 1319 - 1350.

[4] Wheelen, Thomas L.; Hunger, J. David. . 2015. Strategic Management and Business Policy: Globalization, Innovation and Sustainability. 14th Edition. Pearson

[5] Emery, F. E.; Trist, E. L. 1965. The Causal Texture of Organizational Environments. Human Relations, 18, 21-32

[6] Dess, G. G. and Beard, D. W. 1984. Dimensions of Organizational Task Environments. Administrative Science Quarterly, 29: 52 - 73

[7] Hill, Charles W. L.; Jones, Gareth R. 2010. Strategic Management An Integrated Approach. 9th Edition South-Western Cengage Learning

[8] Thompson, Jr Arthur A.; Leon, E., Margaret Peteraf; Gamble, John E; Strickland, A. J. 2016. Crafting \& Executing Strategy: The Quest for Competitive Advantage: Concepts and Cases. 20th Edition. Mc-Graw Hil

[9] Wheelen, Thomas L.; Hunger, J. David. 2012. Strategic Management and Business Policy: Globalization, Innovation and Sustainability. 13th Edition. Pearson. 